\title{
THE PSALM QUOTATIONS OF HEBREWS 1: A HERMENEUTIC-FREE ZONE? ${ }^{1}$
}

\author{
Stephen Motyer
}

\begin{abstract}
Summary
The Old Testament quotations in Hebrews 1:5-13 pose a serious challenge to an evangelical hermeneutic that seeks to be self-conscious and responsible in its handling of biblical texts. These quotations appear, in contrast, wilful and arbitrary in their application to Christ. Assuming that some kind of hermeneutic steers them, even if it produces wilful and arbitrary results, this essay reviews the various suggestions about its nature, and then proposes a version of typology as the guiding hermeneutic-a version which might even be termed 'deconstructionist' in its underlying rationale.
\end{abstract}

\section{Prolegomena}

In 1996 Tyndale Bulletin hosted Richard France's significant essay on the use of the Old Testament in Hebrews, which built upon the work of Richard Longenecker, also published in part in these pages. ${ }^{2}$ This essay seeks to build further upon their foundation, and to take the discussion in a slightly different direction by asking specifically after the hermeneutic of the quotations (chiefly from the Psalms) in Hebrews 1:5-13.

The answer to the question posed in the title is, of course, No. These quotations certainly operate with a hermeneutic that prompts and shapes their deployment here. So the question needs refining, in

1 This paper was first read to the New Testament Research Seminar at London Bible College in February 1998. I thank the group for their comments from which this version has benefited.

2 R.T. France, 'The Writer of Hebrews as a Biblical Expositor', TynB 47.2 (1996) 245-76; R.N. Longenecker, 'Can We Reproduce the Exegesis of the New Testament?', TynB 21 (1970) 3-38; also idem, Biblical Exegesis in the Apostolic Period (Grand Rapids: Eerdmans, 1975) 158-85. 
order to draw out our underlying concern with the quality of this hermeneutic: can it be seen to rest upon reasonable principles, to be acceptable, justifiable in terms that could be received today?

Some will object that this concern is imperialistic-requiring ancient authors to conform to modern norms of acceptability. And of course we must take care not to impose some modern construct onto the data of the text. But we may legitimately bring our concerns to the text, and be open about the fact that, if the use of the Old Testament by the New Testament authors is not in principle reproducible, then we are faced with a theological problem to do with the normativity of the New Testament for us today. For those for whom the foundations of theology lie elsewhere, this problem will not cause the loss of much sleep; but for those in the Protestant tradition who confess 'sola Scriptura' over against other theological norms, the problem is realeven if finally we decide to turn a blind eye to the misuse (as we see it) of these Psalm quotations, because there are solid grounds elsewhere for the normativity of the New Testament.

Others might object that our concern is already one-eyed - because it fails to realise that unreproducible styles of exegesis are part of the cultural given of the New Testament, and are no more to be received normatively today than wearing hats in church or washing each other's feet. This is a comfortable viewpoint, but it fails to reckon with the fact observed long ago by C.H. Dodd, that the use of the Old Testament by the New Testament writers is 'the substructure of New Testament theology'. ${ }^{3}$ It is not hard to show that the central themes and indeed texts of the New Testament are built upon a reworking of Old Testament themes and texts. We are surely right to feel uncomfortable if it appears that the exegesis employed in this reworking is faulty and unrepeatable.

Others again might reply that we can be happy to affirm the results obtained by the New Testament exegesis of the Old, while yet rejecting the methods employed. This is the view of Richard Longenecker, in the essay mentioned above. He writes: 'Our commitment as Christians is to the reproduction of the apostolic faith and doctrine, and only secondarily (if at all) to the specific apostolic exegetical practices. ${ }^{4}$ He particularly has in mind the pesher style of exegesis which was essentially revelatory, involving an inspired 'this is that' connection between a text and a contemporary referent. Such

3 The sub-title of Dodd's influential book According to the Scriptures (London: Nisbet, 1952).

4 Longenecker, 'Can We Reproduce?' 38 
exegesis we cannot reproduce, he says, ${ }^{5}$ but any approaches which approximate to our 'historical-grammatical exegesis' we may affirm. ${ }^{6}$

To this we may make three brief points in reply:

(1) Just such a revelatory, pesher-style exegesis is indeed under current discussion as a possibility for today, and it is precisely the normativity of New Testament pneumatology which is motivating this discussion. $^{7}$

(2) But now, as then, the spirits need to be tested, and 'inspired' exegesis which violates reason and passes radically beyond the basic meaning of a text would certainly be a candidate for rejection today. We still need to ask whether there were any criteria by which pesherstyle exegesis was evaluated in the New Testament-or was any christocentric rereading accepted without question?

(3) Further, and most importantly, there are many instances of pesher-style exegesis in the New Testament which do not claim inspiration as their basis, and among these we may classify the quotations of Hebrews 1. The author reports the words of Scripture as the evidence supporting his contention that Christ is far greater than the angels. The style of the argument is not revelatory, but argumentative, appealing to evidence and reason.

This is the cause of our concern. How are we placed, if we cannot accept the claimed connection between evidence and conclusion in this case?

A chorus of voices says that we cannot. G.B. Caird listed the members of this choir in 1959, all accusing Hebrews of fanciful and far-fetched exegesis. ${ }^{8}$ It would be easy to add plentifully to the list from more recent writing. Friedrich Schröger, for instance, asks whether the quotation of Psalm $101: 26-28^{9}$ in $1: 10-12$ could constitute a proof ('Beweis') for us, that Christ remains though heaven pass away, and replies: 'Naturally, there can be no question here of a proof in the sense of contemporary historical-critical exegesis. The Psalm makes no direct statement about Christ at all. ${ }^{10}$

Longenecker, 'Can We Reproduce?' 36

Longenecker, 'Can We Reproduce?' 38

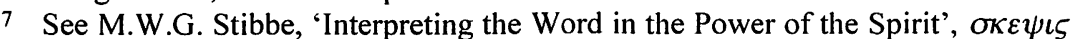
(Autumn 1996) 1-8; idem, 'This is That. Some Thoughts Concerning Charismatic Exegesis', Anvil 15 (1998) 181-193.

8 G.B. Caird, 'The Exegetical Method of the Epistle to the Hebrews', CJT 5 (1959) 44-51.

9 Throughout this article I use the LXX enumeration.

10 F. Schröger, Der Verfasser des Hebräerbriefes als Schriftausleger (Regensburg: Pustet Verlag, 1968) 71: 'Um einen Beweis im Sinne heutiger 
Similarly H.-F. Weiss comments: 'the style of scriptural exposition, as practised in Hebrews...is fundamentally no longer interested in letting Scripture speak with its own voice. ${ }^{11}$ For several others, the question of the reproducibility of Hebrews' exegesis of the Scriptures is simply not discussed (so obviously impossible is it?): S. Kistemaker, H.W. Attridge and W.L. Lane are examples. ${ }^{12}$

We certainly cannot take refuge in the reflection that these quotations are unimportant. This is the preface to Hebrews, the opening statement which sets the scene for the rest of the letter. ${ }^{13}$ The quotations are clearly meant to have a powerful rhetorical effect, picking up and giving the foundation for (note $\gamma \alpha \dot{\alpha} \rho, 1: 5$ ) the amazing presentation of 'the Son' with which the letter opens (1:1-4). We bear in mind the general consensus that the readers are Jewish Christians who need either a foundational presentation of the superiority of Christ to what Judaism offers, or else just encouragement to press on further in their understanding and discipleship, and not become 'sluggish' $(5: 11 ; 6: 12)$. If they are losing their Christian commitment, how will it be reinforced by (let us mention the hardest cases) two quotations which apply to Jesus words originally addressed to Godthe quotation of Deuteronomy 32:43 in 1:6, and of Psalm 101:26-28 in $1: 10-12$ ?

historisch-kritischer Exegese kann es sich hier naturgemäß nicht handeln; über Christus steht in dieser Psalmstelle unmittelbar nichts.'

11 H.-F. Weiss, Der Brief an die Hebräer (MeyerK 13; Göttingen: Vandenhoeck \& Ruprecht, 1991) 181: '[Hier zeigt sich, daß] die Art von Schriftauslegung, wie sie im Hebr praktiziert wird ... vom Ansatz her nicht mehr daran interessiert ist, der Schrift ihre eigene Stimme zu lassen.'

$12 \mathrm{~S}$. Kistemaker says simply, 'The truth of the matter is that the writer composed his Epistle independent of exegetical methods which guide a "modern reader", and shows no concern to explore this divergence theologically (The Psalm Citations in the Epistle to the Hebrews [Amsterdam: Van Soest, 1961] 95). H.W. Attridge remarks only that Dt. 32:43 (quoted in 1:6) 'has been taken out of its context and the pronoun $\alpha \dot{v} \tau \hat{\omega}$..., thus made ambiguous, has been taken as a reference to Christ' (The Epistle to the Hebrews [Hermeneia Commentary; Philadephia: Fortress, 1989] 57). W.L. Lane simply discusses the technical background to Hebrews' use of Scripture in Jewish exegetical techniques, and offers no reflection on how we may appropriate it for ourselves (Hebrews [WBC 47, 2 Vols.; Waco: Word, 1991] 1:cxix-cxxiv).

13 I call Hebrews a 'letter' for the sake of convenience, without prejudice to the discussion of its genre, on which we need not touch. 


\section{The wider setting}

We cannot consider the quotations in chapter 1 in isolation from the rest. Hebrews is full of Old Testament quotations. The precise number is a matter of disagreement, because there is a 'grey area' between quotations and the numerous allusions to Old Testament events, people and texts. ${ }^{14}$ It may be that the author deliberately uses texts in an unusual and provocative way in this opening catena, for rhetorical reasons-hoping that the readers will later realise the appropriateness of its surprising, perhaps shocking application to Jesus. In other words, perhaps we should look elsewhere in the letter for the hermeneutic on which these quotations are based. Caird notes that 'it is characteristic of our author's style to make bold asseverations well in advance of the argument by which he explains or justifies them'. ${ }^{15}$ This can be illustrated from his general technique, but it may apply also to his hermeneutic.

It is important, therefore, to review and consider the basic approaches to the use of the Old Testament in Hebrews as background to our focus on chapter 1. Over thirty years ago Markus Barth provided a classification of approaches which still largely holds. ${ }^{16} \mathrm{He}$ lists three of the four approaches we now survey (the second has appeared subsequently):

\section{The 'Schriftgnosis' approach associated with Rudolph Bultmann and others}

This view holds that the author's relationship with the Old Testament is like that of a socialite with her wardrobe: she picks out the clothes and accessories which match her mood, the occasion, and each other, irrespective of where they came from. So Heilsgeschichte collapses into christology, which seeks texts for rhetorical adornment.

In recent scholarship this position is notably represented by HansFriedrich Weiss:

The exposition of Scripture in Hebrews is nothing other than the proclamation of Christ, according to the hermeneutical 'rule of faith' in Heb.

14 See Lane, Hebrews, 1:cxv-cxvi.

15 G.B. Caird, 'Son by Appointment', in W.C. Weinrich (ed.), The New Testament Age: Essays in Honor of Bo Reicke (Macon, Georgia: Mercer University Press, 1984) 77. Cf. Kistemaker, Citations, 99: 'The author appears to follow the exegetical method of stating something summarily, thereby revealing all the necessary perspectives which are elaborated in the succeeding chapters'.

$16 \mathrm{M}$. Barth, 'The Old Testament in Hebrews: An Essay in Biblical Hermeneutics', in W. Klassen \& G.F. Snyder (ed.), Current Issues in New Testament Interpretation (New York: Harper, 1962) 53-78. The list is on p. 53. 
1:1f. Here the Old is completely absorbed into the New. 'Scripture' and 'confession' are no longer separate entities in Hebrews, but form a unity, for scriptural exposition is nothing other than a particular way of expounding the confession of Christ. ${ }^{17}$

He himself uses the expression 'Schriftgnosis' to describe this approach, ${ }^{18}$ the distinctive character of which is to 'discover in Scripture the contents which match its presuppositions' ${ }^{19}$ As a judgment about Hebrews we may lodge two objections to this approach:

(a) It is not hard to show that Hebrews retains a very clear sense of Heilsgeschichte. Historical distance is by no means collapsed in its use of the Old Testament. In fact, a sense of historical progression from the Exodus, to the settlement in the land, to the kingship and to the present is fundamental to the treatment of Psalm 95 and 'the rest' in Hebrews 3-4. The author's concern is not merely to recruit Old Testament texts and institutions in the service of Christusbekenntnis, but retrospectively to provide an explanation of these texts and institutions which allows the readers to see the plan of God and its progress through to its climax in Christ.

Heilsgeschichte, in fact, is an essential given in the relationship between the author and his ${ }^{20}$ readers, built into their shared belief in God's covenant with Israel. And this leads into the second point:

(b) It is essential that Hebrews actually mounts arguments that would appeal to its readers. An arbitrary plundering and re-assigning of texts would no more convince the readers than Trypho was convinced by Justin's application of some Old Testament texts to Christ. In Dialogue 34 Justin mounts an argument in defence of his view that Psalm 71 refers to Christ, against Trypho's conviction that it refers only to Solomon. Similarly in Dialogue 43 and 66-79 a long argument is mounted to prove to Trypho that Isaiah 7:14 refers to Jesus, and not to Hezekiah. Trypho fails to be convinced, and accuses

17 Weiss, Hebräer, 181, 'Schriftauslegung, das ist im Hebr nach Maßgabe des hermeneutischen Kanons von Hebr 1, If nichts anderes als Christusverkündigung. Das Alte ist hier ganz in das Neue hineingenommen. "Schrift" und "Bekenntnis" sind hier nicht mehr zweierlei, sondern bilden eine Einheit, da ja Schriftauslegung nichts anderes ist als eine bestimmte Art von Auslegung des Christusbekenntnisses.' Cf. also E. Käsemann, Das wandernde Gottesvolk: Eine Untersuchung zum Hebräerbrief (Göttingen: Vandenhoeck \& Ruprecht, 1961) 118.

18 Weiss, Hebräer, 174; cf. Barth, 'Old Testament', 53.

19 Weiss, Hebräer, 175, n. 16: '... die in der Schrift die ihren Voraussetzungen entsprechenden Sachverhalte entdeckt'.

20 'His' is used without prejudice to the sex of the author. Cf. France, 'Expositor', 246, n. 4. 
Justin of producing $\dot{\varepsilon} \xi \eta \gamma \eta \dot{\eta} \sigma \varsigma \varsigma$ which are 'cunning and contrived' ( $\tau \varepsilon \varepsilon \chi \vee \alpha \sigma \mu \varepsilon ́ v \alpha$, Dialogue 79:1).

It is not inappropriate to suggest that the author of Hebrews faces the same need as Justin to find arguments which will convince his wavering or sluggish readers. Rhetorical re-application of well-known texts could be entirely counter-productive. If this is true, of course, it simply increases the difficulty posed by the use of these texts in Hebrews 1, as noted long ago by C.F.D. Moule. The application of Psalm 101:26-28 to Christ, he observed, 'could... have no cogency whatever as a scriptural proof about the status of Christ'. ${ }^{21}$ Schriftgnosis will not allow us an escape-route from this dilemma.

\section{The pre-existence of Christ as an essential hermeneutical key}

This approach has recently been championed by Paul Ellingworth, drawing on the work of A.T. Hanson. ${ }^{22}$ Ellingworth suggests that the author's use of the Old Testament depends upon his belief that

Christ, by whom God has now spoken his final word (1:1f), was alive and active in creation $(1: 2)$ and throughout Israel's history. Any part of the OT may thus in principle be understood as speaking about Christ, or as spoken to or by him. ${ }^{23}$

He suggests that this belief formed a tradition that originated with Jesus himself, citing as evidence the general acceptance of the view that Jesus applied Psalm 22 to himself. ${ }^{24}$

If this belief were part of the presupposition-pool shared by the author and his readers, then our problem is reduced-although, as Ellingworth recognises, it is by no means obvious which texts may appropriately understood as spoken by or addressed to the pre-existent Christ. But again, serious objections may be made to this approach:

(a) The simple application of texts like Psalm 22 to Christ, whether by himself or others, does not in itself claim or depend upon a belief in his pre-existence. This point has been very amply demonstrated, for

21 C.F.D. Moule, The Birth of the New Testament (London: A. \& C. Black, 1966) 77.

22 P. Ellingworth, The Epistle to the Hebrews: A Commentary on the Greek Text (Grand Rapids/Carlisle: Eerdmans/Paternoster, 1993) 41-42; A.T. Hanson, Jesus Christ in the Old Testament (London: SPCK, 1965). Ellingworth however comments that Hanson 'overstates this argument' $(41, \mathrm{n}$. 16). See also for this view B. Lindars, New Testament Apologetic (London: SCM, 1961) 210-13.

23 Ellingworth, Hebrews, 41-42.

24 Ellingworth, Hebrews, 42 and n. 19. 
instance, by J.D.G. Dunn. ${ }^{25}$ The existence of a tradition which might create a basis of argumentation simply lacks evidence.

(b) More significantly, Ellingworth's approach to these Old Testament texts undercuts the contrast between Christ and the angels which is fundamental to the author's presentation. The author works from the view that the Scriptures were given through angels (Heb. 2:2), even though he puts the words of Psalm 22, Isaiah 8 and Psalm 40 into the mouth of Christ in 2:12-13 and 10:5-9-for the era of variety and diversity must be contrasted with the revelation now given by the Son. ${ }^{26}$ There is continuity between the Testaments, but also a strong discontinuity which makes a fundamental rereading essential.

The use of Psalms 22, 40 and Isaiah 8 as direct speech of the incarnate (not pre-incarnate) Christ depends upon a typological use of OT prophecy and kingship, as we will see. A full voice of the preincarnate Christ in these texts would make no sense at all, especially as Psalm 40 goes on to confess sin, weakness and confusion.

\section{The 'sensus plenior' approach, associated particularly with Catholic exegetes}

Spicq is the supreme exponent. Its exegetical results are not dissimilar to those obtained by the 'Schriftgnosis' approach, but it allows Heilsgeschichte a continuing role. The nub of the issue is that

only the Holy Spirit who inspired Scripture can make plain to the reader the christological meaning of that Scripture... We are dealing, therefore, very precisely with spiritual exegesis. Pure logic does not deduce from the texts of the Old Testament the outline of the person and work of Christ: they must be read by the light of the Holy Spirit. 27

Large areas of 'fuller meaning' may therefore emerge from old texts as they are reread in the light of Christ and under the inspiration of the Spirit. Quite clearly, something like this is indeed 'going on' in Hebrews. The author claims the inspiration of the Spirit for his insights into the Tabernacle in 9:8, and builds his use of Scripture on the belief that the Holy Spirit still speaks the words of (for example) Psalm 95: see the introduction to the quotation in 3:7. 'The word of

25 See his arguments against Hanson in his Christology in the Making (London: SCM, 1980) 157-158 and notes in loc.

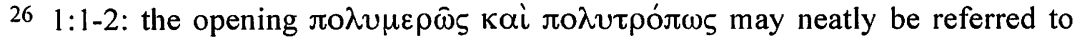
variety of literature and diversity of modes of revelation respectively.

27 C. Spicq, L'Épître aux Hébreux (Paris: Gabalda, 1952) 1:349: 'Seul l'Esprit divin qui a inspiré l'Écriture peut éclairer le lecteur sur le sens christologique de cette Écriture ... Il s'agit donc très exactement d'une exégèse spirituelle. On ne déduit pas des textes de l'Ancien Testament par pure logique l'esquisse de la personne du Christ et son oeuvre, on lit ces textes sous la lumière du Saint-Esprit.' 
God', both in Scripture and in present proclamation, 'is living and active' $(4: 12 ; 13: 7)$. Throughout the letter, we encounter the results of this present-tense 'life' of the word-texts whose meaning has been transformed by their reference to Christ.

But a shared belief in the possibility of fuller meaning does not dissolve the necessity for debate about what that fuller meaning is. 'Pure logic' may not be the foundation, but it plays a vital role. The importance of this point may be illustrated by reference to the methods of exegesis employed in Hebrews. Lane rightly comments that

the principles by which [the author] was guided... and the forms of exposition he adopts were those with which he had become familiar from a life enriched by synagogue preaching. It may be assumed that his audience was thoroughly familiar with the approaches to the text of the OT that are characteristic of this homily from their own exposure to the liturgy and preaching in synagogues throughout the Diaspora. ${ }^{28}$

Lane seems to infer from the traditional nature of the exegetical methods employed that the content of the letter would not therefore have seemed surprising to the first readers. France rightly corrects this misapprehension:

It needs to be added that what we find in Hebrews is not typical synagogue preaching... A non-Christian synagogue hearer would no doubt have felt at home with the style of much of Hebrews' use of the Old Testament, but would have been bewildered by the theological context in which it was set, and therefore also by the results which followed. ${ }^{29}$

To assert a sensus plenior, therefore, does not absolve us from the necessity to enquire after the principles by which some quite traditional exegetical methods were employed to very unusual effect. In any case, as we noted, the author does not make great play of claiming divine inspiration for his interpretations. The formal shape of his writing is, throughout, that of the diatribe, in which arguments are based upon evidence presented rhetorically. ${ }^{30}$

\footnotetext{
28 Lane, Hebrews, 1:cxxiv.

29 France, 'Expositor', 275 (his emphasis).

30 Barth, 'Old Testament in Hebrews', emphasizes the argumentative quality of the use of the Old Testament in Hebrews, calling it 'dialogical interpretation' ( $p$. 65 ). He suggests that the author was particularly influenced by the use of the Scriptures in early Christian worship, and by his pastoral concerns, but offers no suggestions about the underlying hermeneutic involved.
} 


\section{The 'typological' approach associated with Gerhard von Rad and others.}

This approach takes Heilsgeschichte seriously, and within a consciously conceived 'biblical theology' seeks to trace the development of themes within as well as between the Testaments, with the aim of showing how the development has a defensible logic to it, an inner coherence rather than a wilful subjugation of the earlier to the later.

Von Rad's essay on the use of the 'rest' in Hebrews 3-4 well represents the approach. ${ }^{31} \mathrm{He}$ traces the development of the theme from its starting-point in the deuteronomic tradition, where it meant political security, through the Chronicler's addition of the idea of God's rest in Israel, to the remarkable 'enter my rest' of Psalm 95:11 (sharing God's own rest, an idea never entertained by the deuteronomist) - and thence to Hebrews, where a dramatic further step is made by the creative connection between Psalm 95 and Genesis 2:2. Through such a development, a typological relationship is set up between the earlier stages and the later.

A reawakened interest, amongst New Testament scholars, in typology was what prompted the remarkable, and seminal, 1959 essay by G.B. Caird. ${ }^{32}$ From a formal point of view, Caird provides the helpful insight that the argument of Hebrews is shaped around four especially crucial quotations (Pss. 8, 95, 110 and Je. 31), which control successive sections of the letter (chs. 2, 3-4, 5-7 and 8-10 respectively). ${ }^{33}$ This insight has now been taken further by France, who has convincingly shown that Habakkuk 2:3-4, Proverbs 3:11-12 and the Mt Sinai motif similarly shape Hebrews 11 and $12 .{ }^{34}$

But beyond structure, Caird maintained that the four texts he identified all 'declar[e] the ineffectiveness and symbolic or provisional nature of the Old Testament religious institutions', and thus were used as part of a campaign to prove 'the self-confessed inadequacy of the old order'. ${ }^{35}$ In other words, the author's strategy, according to Caird, was to show the Old Testament undermining

\footnotetext{
31 G. von Rad, 'There Remains Still a Rest for the People of God: An Investigation of a Biblical Conception', in The Problem of the Hexateuch and Other Essays (London: Oliver \& Boyd, 1966) 94-102.

32 Caird, 'Exegetical Method'.

33 Caird, 'Exegetical Method', 47. A similar suggestion was made by Kistemaker, Psalm Quotations, 101 (and following), although he included Psalm 40 in the list (quoted in Heb. 10:5-8) rather than Je. 31.

34 France, 'Expositor', 265-67.

35 Caird, 'Exegetical Method', 47, my emphasis.
} 
itself, so that out of its 'self-confessed inadequacy' there might emerge a typological relationship with Christ who is the fully adequate answer to the world's need. This most stimulating suggestion has not, so far as I am aware, been developed further by any subsequent study. France, though he builds upon Caird in other respects, does not take up this aspect of his treatment.

Typology, as an explanatory tool in the hands of the student of biblical history, has the potential to offer understandings of the relationships between earlier and later elements in the story which do not violate the integrity of either element, and to satisfy the concern which we are seeking to address in this paper. Unfortunately, it lies beyond the scope of this study to attempt a full evaluation-either of this potential or of Caird's particular proposal. However we will bear both in mind as we now ask more directly about the quotations in ch. 1 , for if this overall approach proves fruitful here, with these most challenging texts, then a presumption will be created in its favour elsewhere.

\section{In search of a hermeneutic for Hebrews 1:5-14}

We face the difficulty that this opening catena is different from anything later in the letter, especially if overall the letter is structured around the exposition of certain crucial texts. Here there is no such dominant text, but a striking train of seven quotations gathered on the rabbinic principle of haraz (the connecting of pearls on a string).

Some have sought to argue that the author employs an already existing testimonia-collection of messianic texts: most notably F.C. Synge $^{36}$ and H.W. Montefiore. ${ }^{37}$ This view does not receive the support of many, because the catena shows such clear signs of being designed for its role here in Hebrews. More widely supported is the view that these texts, used without explanation, must have already been accepted as messianic by author and readers alike. ${ }^{38}$ If this is so, the problem of explaining how they could have argumentative force with the readers is largely solved. They need no justification, and the

36 F.C. Synge, Hebrews and the Scriptures (London: SPCK, 1959): cited by numerous scholars, e.g. Barth, 'Old Testament in Hebrews', 73; Ellingworth, Hebrews, 109.

37 H.W. Montefiore, The Epistle to the Hebrews (London: A. \& C. Black, 1964) 43-44.

38 So Longenecker, Biblical Exegesis, 180-81; France, 'Expositor', 255-56; Ellingworth, Hebrews, 109-110. 
only novelty consists simply in their use to prove the superiority of Christ over the angels. ${ }^{39}$

But there are two difficulties with this: one minor, and one major. The minor difficulty is that, if the readers are already accustomedtaught by Psalm 44 and 101-to calling Christ $\theta \varepsilon o ́ \varsigma$ and кúpros, and if they already believe that he will remain, though the earth pass away, then it is hard to see why the author is so concerned about them. This will surely be fatal to the 'relapse' theory (which holds that the readers are in danger of abandoning their Christian commitment and slipping back into Judaism). For if they were becoming inclined to dispute (like Trypho) the rightness of calling Christ $\theta \varepsilon$ ó $\varsigma$ and кúpios on the basis of texts like these, then the author will surely not serve his purpose by simply quoting them as if there were no problem. So we will find ourselves favouring the 'encouragement' theory, which holds that the author simply wants to move them forward to greater faith and activism.

The major difficulty is that this does nothing to help us with our hermeneutical problem over the use of these texts. If author and readers alike accepted without question that these texts were applicable to Christ, then we are cast in the role of those who waver, and wonder, and want answers to the questions which nag us.

But maybe, in fact, this is the author's purpose?-deliberately to tantalise, provoke, even upset, so as to stimulate the kind of reflection represented by this essay? The evidence is very slim that Deuteronomy 32:43 (quoted in 1:6) was read in earliest congregations as an address to Christ (there is no evidence, apart from this passage) - and all the other uses of Deuteronomy 32 in the New Testament support the view that the first Christians understood it within its historical parameters as 'the Song of Moses'. ${ }^{40}$ Similarly there is no other evidence that Psalm 101 was read messianically by the first Christians. Even Justin steers clear of this one-although he happily takes up and develops the messianic interpretation of Psalm $44 .^{41}$

Such as it is, the evidence supports the view (I contend) that the author is using these texts with hermeneutical 'gay abandon'. He has his reasons, but he does not reveal them. He will later gently tease his

\footnotetext{
39 So Montefiore, Hebrews, 43f.

40 See e.g. Rom. 10:19; 15:10.

41 Justin Dialogue 56, 63, 86. His use interestingly reveals, as Schröger, Schriftausleger, 64, n. 5 (following Riggenbach) notes, that Ps. 44 was not understood messianically by Jews.
} 
readers, that they still need to be taught 'the very basic first steps in

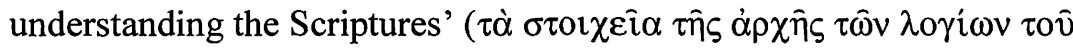
$\theta \varepsilon \circ \hat{v}, 5: 12$ ), having fired five chapters of intense scriptural engagement at them. This seems to be his rhetorical strategy: to baffle, overwhelm and fascinate his readers, to tantalise them with glimpses of vistas of truth yet to be discovered, and thus to engage them in the growth which has eluded them so far. Hebrews has had that effect on readers ever since.

If this is so, then it is quite possible (a) that we are meant to be puzzled and shocked by these quotations, and (b) that a hidden hermeneutic is there to be found. Will it give itself up? We will follow the reliable principle of moving from the known to the unknown:

\section{Texts certainly understood as messianic}

It would be reasonable to suppose that texts already regarded as messianic within Judaism would be treated as such by the first Christians. Two of the six christological texts here ${ }^{42}$ fall into this category: the first pair, from Psalm 2:7 and 2 Samuel 7:14 // 1 Chronicles 17:13 in 1:5. These texts both occur in a messianic context in 4QFlorilegium, although they are not quoted alongside each other, as here, and in fact Psalm 2:1 is quoted rather than 2:7. But clearly the Davidic promise in 2 Samuel 7 is brought into connection with the prophetic 'Branch of David' tradition, and this in turn is linked with Psalm 2 which is interpreted eschatologically. In line with this we find Psalm 2 being interpreted christologically throughout the New Testament, in a variety of connections. ${ }^{43}$

In our search for a hermeneutic we may certainly employ Caird's argument, which is not dissimilar to that used in Acts 2:24-31 with reference to Psalm 15. There Peter argues that, because David knew that he himself would die, he must have been speaking about his promised Son when he spoke of 'not seeing corruption'. In fact the argument applies more neatly to Psalm 2 than to Psalm 15, because it concerns a promise of God. It would run as follows: Psalm 2, building upon the dynastic promise of 2 Samuel 7, holds out a prospect of world rule before the Davidic king. But this promise was never fulfilled under any of the actual occupants of the throne in Jerusalem. In fact, quite the opposite: the boundaries never expanded, and the Davidic dynasty finally failed completely. The promise therefore

42 Not counting the quotation of Ps. 103:4 in 1:7 which serves as a foil to the others.

43 E.g. Acts $4: 25 ; 13: 33$; Rev. $2: 26 ; 12: 5$. 
awaits fulfilment still, and the author associates himself with mainstream Christian thought as he attaches its fulfilment to Christ who is 'heir of all things' (1:2). Within its own terms (relating to the Jerusalem kingship) the Old Testament 'deconstructs' itself, and provides the basis for a typological application to Christ. ${ }^{44}$

This hermeneutic depends upon a historical judgment, just as indeed does the use of Psalm 2 in 4QFlorilegium. The founding vision of the Davidic dynasty has not yet been fulfilled, and therefore it feeds an eschatological expectation.

The next quotation $(1: 6)$ is introduced by language redolent with 'Davidic' overtones: the term $\pi \rho \omega \tau$ tó $\tau о \varsigma$ is used of the Davidic king in Psalm 88:28, to express just the theology of Psalm 2:7—although interestingly this is the Psalm which exalts the Davidic promises in high-flown terms only to complain that they have not been kept (88:39ff.). ${ }^{45}$ But attached to this 'Davidic' introduction is a text which at first sight has nothing to do with the Davidic tradition, Deuteronomy 32:43 - and which may have been as surprising to the first readers as to us. We return to this below.

Also to be classified here is the closing quotation (1:13) from Psalm 109:1. The evidence that this was read messianically in Judaism is very slight. So it may well be that its prominent use in the New Testament derives from Jesus himself (Mk. 12:35-37 par.). Its use in Hebrews seems to build upon an accepted wider use, for (as Ellingworth notes ${ }^{46}$ ) the quotation appears to presuppose the

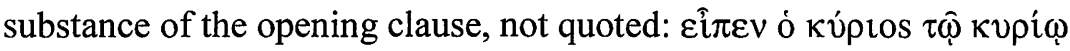
$\mu \mathrm{ov}$. In the light of this it is interesting to note the use elsewhere, not here, of the argument which distances the Psalm from its original setting: in Acts 2:32-34 Peter argues that the Psalm cannot have been adddressed by the Psalmist to David, because David never ascended to heaven. So David must himself have been the Psalmist, addressing Yahweh about another 'Lord' who will sit at God's right hand.

\footnotetext{
44 I use the expression 'deconstruct' without wishing to align the author to the Hebrews with Jacques Derrida! Unlike Derrida, our author takes language very seriously - in fact his argument seems to depend on listening to what the Scriptures actually say, and thus allowing internal tensions to appear.

45 The other possibilities are an allusion to Adam as $\pi \rho \omega \tau$ ó The Epistle to the Hebrews [Grand Rapids: Eerdmans, 1964] 16), or to Israel as

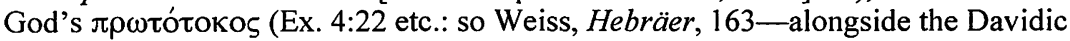
reference). There may be some substance in the 'Israel' overtone, because Israel's sonship is also a theme in Dt. 32 (vv. 6, 18f.). But the Davidic 'flavour' seems to predominate.
}

46 Ellingworth, Hebrews, 130. 
So the catena begins and ends with texts certainly used as messianic in the earliest church, whose hermeneutic seems to depend upon the kind of argument which Caird regards as typical of Hebrews.

\section{Texts which may be readily understood as messianic on the same principle}

We may extend this line of thought without difficulty to Psalm 44:7-8, quoted in 1:8-9. This Psalm was not interpreted messianically in Judaism or elsewhere in the New Testament (although, as we have seen, Justin used it prominently). But it too promises universal victory and rule to the Davidic king (44:4-6, 17-18). It is likely that the author is right in reading the LXX as addressing the king as 'God' (to express vividly his role as regent on behalf of Yahweh?), though it is less likely that the LXX rightly interprets the Hebrew here.

The messianic use of this Psalm may rest on the same argument. Schröger quotes E. Riggenbach:

This promise, to a representative of the Davidic house, was never fully realised in any descendant of the royal dynasty. It therefore became a prophecy applied to the eschatological King, in whom the idea of the Davidic kingship would reach its final realisation. ${ }^{47}$

Schröger does not clarify whether Riggenbach is referring to a development within Judaism, or within the early church, or simply in the author's circle. Delitzsch argued along similar lines that the Psalm became messianic within Judaism, ${ }^{48}$ but the evidence for this is lacking. We may simply be in touch with the hermeneutic of our author himself here. And clearly the fact that a human being is addressed as 'God' reinforces the same point: in which actual representative of the Davidic house was the exercise of divine regency so clear that this title became even remotely appropriate?

47 Schröger, Schriftausleger, 65-66, quoting the 1922 edition of Riggenbach's commentary, p. 22: 'Was hier einem Vertreter des davidischen Hauses zugesagt wird, hat in keinem Sprößling dieses königlichen Geschlechtes seine volle Verwirklichung gefunden und wird so zur Weissagung auf den König der Endzeit, in welchem die Idee des davidischen Königtums zu abschließender Realisierung gelangt.'

48 F. Delitzsch, Commentary on the Epistle to the Hebrews (Edinburgh: T. \& T. Clark, c 1868) 78: 'The original reference of this forty-fifth Psalm to the person of a king who failed to realize it is, after that failure, laid aside and forgotten, but the Psalm itself remains standing as a prophecy which still awaits fulfilment.' 


\section{Texts which stretch and tease but extend the same line of thought}

We turn finally to the two quotations which cause the most difficulty. Can our reflections so far help us to uncover the hermeneutic of the quotation of Deuteronomy 32:43 in 1:6, and of Psalm 101:26-28 in $1: 10-12$ ?

The first step is to dispute whether in fact Deuteronomy 32 is the source of the quotation in 1:6. Clearly the language has been influenced by Deuteronomy 32:43, probably because Deuteronomy 32 was one of the $\dot{\omega} \delta \alpha i$ attached to the Psalter and sung in hellenistic synagogues. The wording of the quotation, in fact, is closest to that in the second Ode, ${ }^{49}$ which Philo regularly calls the $\dot{\phi} \delta \grave{\eta} \mu \varepsilon \gamma \alpha \dot{\lambda} \lambda \eta{ }^{50}$ Left entirely out of account by some scholars ${ }^{51}$ is the possibility that Psalm 96:7 is in the author's mind here, even though the wording has been influenced by the familiarity of the second Ode.

This possibility is highly suggestive, and illustrates the extent to which the LXX (or some very similar text) was the author's Bible. For the heading in Psalm 96:1 LXX (not MT) brings the Psalm into the orbit of the David-ideology of Psalm 2: $\tau \hat{\varphi} \Delta \alpha v i \delta$, ö $\tau \varepsilon \dot{\eta} \gamma \hat{\eta} \alpha \hat{v} \tau o \hat{v}$ $\kappa \alpha \theta i \sigma \tau \alpha \tau \alpha \mathrm{l}$. $\kappa \alpha \theta i \sigma \tau \eta \mu \mathrm{t}$ is also used of the establishing of the King on Mount Zion in Psalm 2:6, and there also the kings are commanded to

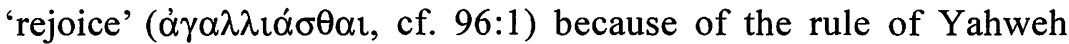
visible in his enthroned King. $\gamma \hat{\eta}$ is the usual term for the covenant 'land', and it is clearly used in this sense in the title in 96:1a; but it is also frequently used for 'the earth', and this is its sense in Psalm 2 (vv. 2, 8, 10) and in the rest of Psalm 96 (vv. 1b, 4, 5, 9).

The establishing of David's kingdom (David's 'earth'), marked in the LXX as the real occasion of Psalm 96, is a token of the establishing of the rule of the kúpıos over all the earth. In the LXX these two rules are being treated as, in essence, expressions of each other. We see this also in Psalm 2 where the Davidic king will shepherd the nations with a rod of iron, but they are called upon to 'serve Yahweh with fear' (2:11). And therefore the summons for the angels to worship the kúpros in Psalm 96:7 (LXX) may be treated as theologically equivalent to a call to bow before the Davidic king,

\footnotetext{
49 With the exception of the omission of the article before ${ }^{\prime \prime} \gamma \gamma \varepsilon \lambda$ ot. Dt. $32: 43$ actually has vioi $\theta \varepsilon$ ov rather than '

50 E.g. Quod Det. 114, Leg. Alleg. 3:105.

51 E.g. Lane, Longenecker, France. More usual is the view that this is a mixed quotation (e.g. Weiss, Hebräer, 161), although Attridge, Hebrews, 57 argues that Ps. 96 is the primary source.
} 
whose 'land' has been established. The LXX by the addition of this heading gives the Psalm a different quality, which the author readily exploits.

The author is thus moving within the orbit of the Psalms' Davidic and Zion theology, and finding within it tokens of a staggering association of kingdoms which makes no historical sense until the greater David comes who truly is 'the heir of all things'. This is certainly an argument which we may affirm today.

We may handle Psalm 101 in a similar way. This 'most perplexing of all' Old Testament quotations applied to Christ ${ }^{52}$ derives its puzzling quality not least from the fact that it needs to have some cogency from within Judaism, and not just from within a presupposed christology. Once again, it appears that the author is relying on the LXX interpretation of the Psalm. A vital difference between LXX and

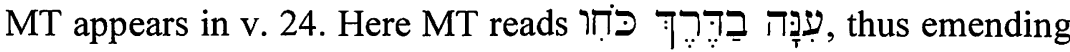
the last word with a 'Qere' in order to yield an acceptable meaning, 'he has humbled my strength in the way' (NRSV, 'He has broken my strength in midcourse'). ${ }^{53}$ This forms a nice poetic parallelism with the second line of the verse ('he has shortened my days'), and carries on appropriately from the lament of the 'poor man' in the first part of the Psalm.

The LXX, however, has translated ענה with $\alpha \varepsilon \varepsilon \kappa p i \theta \eta$, as if it were

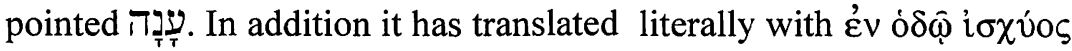
$\alpha \dot{v} \tau o \hat{v}$. Who replies to whom, and whose strength is this? In fact this uncertainty can lead to a different analysis of the Psalm, particularly in the light of the nexus of 'Davidic' themes and associations which we have seen to be vital for the other Psalm quotations in this catena:

In verses 1-12 we have the complaint of the 'poor man' ( $\pi \tau \omega \chi 0$ 's)

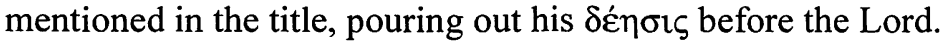

In verses 13-23 we hear the confidence of this 'poor man' that his $\delta \varepsilon ́ \eta \sigma ı \zeta$ has been heard: he looks forward to the Lord's deliverance of Zion, which will include bringing nations and kings to fear his name (16): the Lord will bow down from his holy height (20), to hear the groan of the oppressed, to free the children of the executed (21), to announce in Zion $\tau$ ò óvo $\mu \alpha$ kvpíov and his praise in Jerusalem (22), while peoples and kingdoms are gathered together to serve the Lord

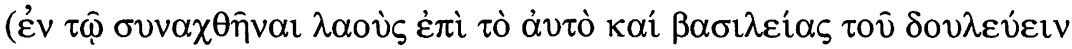
$\tau \hat{\omega} \kappa v p i(\omega)$. We may readily connect this with the emphases in Psalms

52 Moule, Birth, 77.

53 For עִ עונָּה see BDB 776a. 
2, 44, 109 and 96 on precisely these themes-the gathering of the nations to bow to Yahweh as represented by his anointed in Zion.

Then in verses 24-29 we hear the address of the 'poor man' to the кúptos mentioned in verse 23 . He replies to this Lord, whom kingdoms will serve, 'in the way of his strength', that is, in relation to the Lord's role as mighty deliverer, and describing his rule in the exalted language which Hebrews applies to 'the Son'.

Within the setting of this Davidic / Zion theology, in which Yahweh's kingdom is cognate with and implicit in the Davidic rule in Zion-with all the historical tensions this produces-it is certainly possible that the author of Hebrews read Psalm 101 in this way, deriving his reflections from the distinctives of the LXX text. He hears that overlap between the kingdoms developing into an overlap of the name (both Yahweh and the Davidic king are kúptos), and thence into an overlap of the address, whereby the kv́ptos of verse 23 (the Davidic king) is then addressed as the kúptoৎ who founded the earth, whose kingdom will last for ever. It is a measure of his dependence on the LXX, of course, that kv́ple in verse 26 is not matched by anything in the MT. ${ }^{54}$

If this is indeed how he read the Psalm, then the underlying hermeneutic will again be that discrepancy between aspiration and historical reality which creates a typological projection into the future, making the text available (as word of God) for a rereading in relation to Jesus Christ. This, I would argue, is an acceptable hermeneutic, because it builds upon an understanding of Davidic kingship which is well-founded historically and takes seriously the historical realities of dynastic decline and prophetic hope. Here too, by the tensions within its very data, the Old Testament 'confesses its own inadequacy' (to

54 B.W. Bacon, 'Heb 1,10-12 and the Septuagint Rendering of Ps 102,23', ZNTW 3 (1902) $280-85$ is the only previous attempt, of which I am aware, to explain the author's usage through his dependence upon the LXX. His view is adopted reluctantly ('speculative and ... far-fetched. But ... perhaps the only intelligible explanation') by Moule, Birth, 79. Bacon understands the last section of the Psalm (vv. 24-29) as an address by God to the Messiah, calling him кúpıє, with the change of speaker marked by $\alpha \pi \varepsilon \kappa \rho i \theta \eta$ in LXX v. 24. The objection to this is the

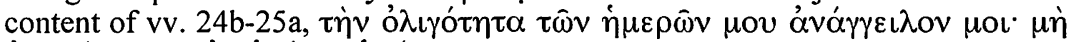

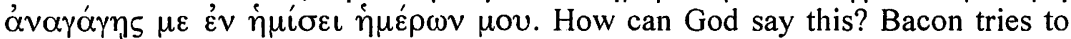
make exegetical capital out of this difficulty by arguing that it is the source of the notion of the shortening of the last days (Mt. 24:22), but this certainly seems 'farfetched'.

It seems much more natural to understand $\alpha \dot{\alpha} \varepsilon \kappa \rho i \theta \eta$ as marking the return of the speaker of vv. 2-16. The change from $2 \mathrm{nd}$-person to 3rd-person address in v. 17 implies a change of speaker in the course of the middle section, and underlines the status of vv. 13-23 as an answer to the prayer of vv. 2-12. 
use Caird's expression)—or perhaps better reveals its own discomfort, living with an understanding of kingship which bore very little relation to reality 'on the ground'.

It seems likely, as we have seen, that the author mixes accepted messianic texts with others which he adds on the basis of his own reflection, but which are interpreted by employing the same hermeneutic as the widely-used texts. Thus he hopes that, surprising and shocking though it may be to propose Psalm 101:26-28 as an address to the Messiah, some thought will reveal how appropriate it is.

In order to complete the picture it would be necessary to search for this hermeneutic elsewhere in the letter, but that is beyond the selfimposed remit of this essay. Suffice it to say that it obviously fits the quotation of Psalm 8 in 2:6-8, where 'we do not yet see' (2:8) gives the game away. The Psalm ascribes to humankind a position over 'all things' which does not correspond with experience-until we 'see Jesus' (2:9), who allows this nonsensical statement still to be word of God, because he is an ' $\alpha \theta \rho \omega \pi$ s 5 for whom it is true, and through whom it will be true for humankind in the End. This strategy fits also the use of the 'rest' in Hebrews 3-4 (Ps. 95 'deconstructs' the belief that entry into the Land meant 'rest'), and fits too the use of Melchizedek in Hebrews 7 (Ps. 109:4 'deconstructs' the Aaronic priesthood by proposing another priesthood: see Heb. 7:11)—and so on.

\section{Conclusion}

I suggest, therefore, that there is indeed an underlying hermeneutic operative in this opening catena of quotations. Its dimensions are not made clear at this point, but emerge gradually as the letter unfolds. It is a hermeneutic which has something in common with the Rabbinic gezerah shawah principle, ${ }^{55}$ whereby texts with common terms or themes are connected and expounded in the light of each other. But our author does not have a harmonistic motivation: he looks for the tensions, even the contradictions, between texts, which allow him (a) to assert that Jesus is the fulfilment, the answer to the puzzle, and (b), paradoxically, to reinstate the Old Testament as 'word of God' witnessing in its 'partial and fragmentary' way $(1: 1)$ to the Son who is the final Word.

55 See Longenecker, Biblical Exegesis, 34. 
I further suggest that this hermeneutic is perfectly acceptable today. We could even extend it beyond the texts actually handled this way in Hebrews: for instance we could affirm Justin's messianic interpretation of Psalm 71 on the ground that Solomon was never like that, or exploit the contradiction between Amos 3:1-2 and Amos 9:7 (the covenant: permanent or dissoluble?) to point ahead to Jesus in whom God's covenant commitment to Israel is fulfilled, or use David's discovery that 'high-handed' sin could be forgiven (2 Sa. 12:13; Ps. 50:19; contra Nu. 15:27-31) to point forward to the full dimensions of atonement in Christ. Within biblical theology, this hermeneutic allows typology to function both historically and theologically: historically, because it makes real historical judgments about the tensions within Old Testament traditions, and theologically, because it refers these tensions beyond their original historical and social matrix to Christ as their 'real' implied referent. ${ }^{56}$

56 See Christopher Seitz, 'The Historical-Critical Endeavor as Theology', Word Without End: The Old Testament as Abiding Theological Witness (Grand Rapids: Eerdmans, 1998) 28-40, for a penetrating critique of von Rad's failure to hold history and theology together in his 'typological' approach to biblical theology. Further on this; see my essay 'Two Testaments, One Biblical Theology', in J.B. Green and M.M.B. Turner (ed.), Between Two Horizons (Grand Rapids: Eerdmans, forthcoming). 